\title{
Firm Resources, Corporate Governance and the Disclosure of Intangible Assets
}

\author{
Walter P. Mkumbuzi ${ }^{1}$ \\ ${ }^{1}$ The Department of Accountancy, The University of Zimbabwe, Zimbabwe \\ Correspondence: Walter P. Mkumbuzi, The Department of Accountancy, The University of Zimbabwe, P O Box \\ MP167, 630 Churchill Avenue, Mt. Pleasant, Harare, Zimbabwe. Tel: 263-71-680-0268. E-mail: \\ wmkumbuzi@commerce.uz.ac.zw
}

\author{
Received: April 13, 2015 Accepted: June 10, 2015 Online Published: August 18, 2015 \\ doi:10.5539/ass.v11n24p113 URL: http://dx.doi.org/10.5539/ass.v11n24p113
}

\begin{abstract}
The paper investigates the determinants of intangible asset disclosure with reference to the interaction of heterogeneous asset and governance characteristics of firms. Specifically, it considers R\&D intensity as a measure of asset heterogeneity and multiple proxies for the effectiveness of the firm's corporate governance mechanisms and structures of accountability. Intellectual capital attributes are applied as the measure of disclosure quality and as the signalling mechanism through which management are able to inform markets of their competitive advantage. By applying the resource based view of the firm and signalling theory, the paper extends prior research on the determinants of intangibles disclosure through an analytical framework that examines the interaction of firm resources, corporate governance and intangibles disclosure. The theoretical framework combines the RBV of the firm in confirming intangibles as a necessary feature of disclosing firms' asset base and signalling as the means with which management disclose their competitive advantage. The results of the analysis indicate a positive relationship between R\&D intensity, complexity and scope of activity and the presence of quality signalling responses. Also, the separation of the roles of chair and non-executive director, complemented by experienced non-executive directors promote quality signalling through the disclosure of intellectual capital attributes. These findings support the view that corporate governance mechanisms are only effective when applied in combination. Governance mechanisms bring about transparency and accountability through disclosure of these intangibles despite the potential competitive losses. The lack of proprietary costs that might otherwise restrict disclosure might be attributed to competitors' inability to imitate such intellectual capital resources and therefore their inability to duplicate such signals. The findings confirm the interaction between heterogeneous assets and governance mechanisms in the disclosure of intangibles as signalling mechanisms for management.
\end{abstract}

Keywords: intangibles, intellectual capital, disclosure, corporate governance, research and development, competitive advantage, signalling and resource based view

\section{Introduction}

\subsection{Background}

The paper explains the disclosure of intangibles in corporate balance sheets in terms of the interaction of the possession of unique resources and the structure of governance and accountability. Such an approach is potentially fruitful as the firm's senior management are simultaneously concerned with the development of strategies likely to result in competitive advantage and their accountability for the resources deployed to sustain such advantage. Put another way, if managers invest in resources that create competitive advantage they have an incentive to signal such investments where competitors might find such signals difficult to replicate, but may nonetheless not do so where their activities are poorly monitored by capital market participants. Mere possession of resources therefore may not be a sufficient condition for their disclosure in the annual report. Although intangible assets and the role of creative workers are becoming increasingly important in the world economy and at individual firm level associated with the creation of competitive advantage (Lev, 2001), there has been no systematic investigation of the link between resource attributes, governance and the disclosure of intangible assets. 


\subsection{Intangible Assets - a Key Source of Competitive Advantage}

Previous literature has examined the separate effects of resource attribute on intangible asset disclosure (Archambault \& Archambault, 2003; Citron, Holden, Selim, \& Oehlcke, 2005), the role of such disclosures as signals (Bozzolan, Favotto, \& Ricceri, 2003; Garcia-Meca, Parra, Martinez, \& Larran, 2005) and the role of governance factors such as board composition on disclosure (Haniffa \& Cooke, 2002; Lufti, 1989, Malone, Fries, \& Jones, 1993). Taken together the results of these and other studies suggest that investment in intangible resource and their disclosure through transparent governance structures are potential mechanisms to secure competitive advantage and its corollary of superior returns to shareholders. However, previous studies have not theorised such a relationship nor presented fully integrated tests of the relationships between them. Understanding of these relationships is important, since, for an increasing number of industries, and more especially in the service and innovative industries intangibles have become a key source of competitive advantage (Marr, Gupta, Pike, \& Roos, 2003). In order to contribute to this literature therefore, and to enhance our understanding of the determinants of intangible disclosures, a theoretical framework is suggested linking disclosure with the impacts of the firm's asset base, specifically R\&D intensity, and the effectiveness of the firm's corporate governance mechanisms and structures of accountability. The theoretical relationships are discussed in section 1.3 below and results from prior empirical surveys assessed. The paper then examines the determinants of disclosures concerning intangible assets and the joint and separate impact of the firm's asset base and governance structure. These propositions are tested using a cross-sectional analysis of a large sample of disclosures made by UK firms and the results are reported in section 3 below. Section 4 discusses the findings and draws the conclusions.

\subsection{Firm Resources, Corporate Governance and Disclosure: An Analytical Framework}

For the purposes of the analysis below, it is assumed that managers are motivated to achieve competitive advantage, either for the benefit of themselves, or of shareholders and their chosen disclosure strategy is governed by this attitude. Therefore, disclosures of intangibles are a function of the firm's competitive strategy and the requirement to signal the presence of assets likely to create competitive advantage to capital markets. Sustained competitive advantage (SCA) is defined as delivering sustainable above-normal returns (Peteraf, 1993) and is likely to be achieved as a result of the possession of unique assets. According to the theory of competitive heterogeneity such assets might be tangible, but possessed by one firm and not another as a result of monopolistic market conditions. In contrast, according to the resource-based view of the firm and in particular, the knowledge-based view of the firm (Grant, 1996); sources of SCA are located in assets that cannot be purchased in a market. The resource-based view (RBV) explains the competitive advantage of organisations in terms of bundles of resources (Amit \& Schoemaker, 1993; Rumelt, 1984), which are valuable, rare, inimitable and non-substitutable (VRIN) (Barney, 1991). Super-normal profits consistent with the organisational aspects of SCA (Barney, 1991) arise from firm specific assets, managerial economies of scope, and organisational mechanisms of co-ordination (Penrose, 1959; Teece, 1980; Coff, 1997). ${ }^{\mathrm{i}}$ As the firm invests in assets such as specialised production facilities, trade secrets and engineering experience (Teece, Pisano \& Sheun, 1997) over time (Dierickx \& Cool, 1989), tacit knowledge is embedded in technically complex routines. According to the knowledge-based view, SCA arises from such routines (Spender, 1989; Nonaka, 1991). Such assets typically have intangible characteristics and accordingly the RBV approach is adopted here as a tool for analysing intangible disclosures, typically linked to firm value creation.

Intangible, as opposed to merely heterogeneous resources may therefore be more likely to be disclosed to the capital market as signalling devices. The monopolistic possession of tangible resources, for example a telephone cable network, is likely to be well known by competitors, investors and regulators and is therefore less likely to be the subject of further elaboration in the annual report. Conversely, the creation of RBV intangibles, for example investment in organisational and technical processes, is likely to be less well understood by capital market monitors, creating a potential moral hazard and information asymmetry problem, the logical solution to which is enhanced accounting disclosure. Moral hazard and information asymmetry problems associated with intangible assets may be exacerbated by the mendacious but unverified assertions of inferior firms to have made equivalent investments to their competitors, thereby staking a claim to inequitable shares in superior profits. More fundamentally, where such investments have occurred, in the absence of disclosure there is no alternative mechanism for the capital market to adjust returns to reflect the abnormal profits associated with SCA. There is thus a quality signalling rationale (Akerlof, 1970; Spence, 1973; Healy \& Palepu, 1993) for disclosure of investments in intangibles. Toms (2002) uses this approach, with reference to environmental disclosures, to link quality signalling using accounting disclosure to the RBV. Other empirical studies have investigated the signalling properties of intangible disclosure and found that high tech industries investing heavily in intangibles 
aim to promote competitive advantage through disclosure of R\&D and technological development processes (Bozzolan et al., 2003), or to promote the confidence of investors and customers through such disclosures (Garcia-Meca et al., 2005). A possible extension to these empirical studies can be developed by following Toms (2002) who argues that governance characteristics will mediate the level of disclosure, so that full disclosure will occur where monitoring mechanisms are more effective. Theoretical approaches to corporate governance, for example in new institutional economics argue that an effective board will reduce managerial opportunism and diffuse agency conflicts (Leftwich, Watts, \& Zimmerman, 1981; Fama \& Jensen, 1983).

\begin{tabular}{cccc}
\hline & \multicolumn{2}{c}{ Strength of Governance Structure } \\
\hline & Less effective & More effective \\
\hline \multirow{3}{*}{ Organisational Resource Base } & Replicable & Quadrant 1 & Quadrant 2 \\
& Non-replicable & Quadrant 3 & Quadrant 4 \\
\cline { 2 - 4 } & & Moderate disclosure & High disclosure \\
\cline { 2 - 4 } & & &
\end{tabular}

Figure 1. Resources, governance characteristics and disclosure: an analytical framework

Figure 1 combines the RBV, signalling and governance elements of these theories to explain the extent of intangible disclosures. On the vertical axis, the resource base of the firm is represented by a continuum, which at one extreme consists of explicit and easily replicable resources and at the other consists of highly tacit and very difficult to replicate intellectual and similar intangible assets. On the horizontal axis, the signalling incentive is represented by a continuum, which at either extreme consists of strong governance mechanisms likely to lead to full disclosure and at the other weak mechanisms likely to lead to opacity. The framework forms the basis for developing testable hypotheses to explain the disclosure of intangible assets. In quadrant one, where the asset base is replicable, for example because it consists of tangible assets that can be purchased in the market, and governance mechanisms are of limited effectiveness, the lowest disclosure outcome is predicted. In quadrant 2, where the asset base is replicable and governance mechanisms are more effective, disclosure is the same as in quadrant 1 , since notwithstanding more effective governance, the asset base does not dictate truthful or more extensive disclosure because the firm has no intangible assets related to SCA. In quadrant 3, where the asset base is non-replicable, and therefore consisting of non-market purchasable intangibles, but the governance mechanisms are less effective, disclosure will reach intermediate levels. In quadrant 4 , where the asset base is non-replicable and the governance mechanisms are more effective, disclosure will be at its highest, because although possessing similar asset bases as quadrant 3 firms, governance mechanisms are likely to overcome managerial reticence about disclosure, induced for example by concerns about the competitive costs of the disclosures. The purpose of the paper is to test the implied separate and joint relationships in Figure 1. Before doing so, it is important to consider suitable measures so that the resource base, governance attributes and disclosure attributes can be quantified. Prior studies have focused on disclosure and the vertical or horizontal continua in Figure 1. It is therefore important to examine these studies before deriving suitable proxies for testing. Disclosure measures are common to all studies and are discussed separately in section 2.1 below. Relatively little explicit use has been made of RBV in accounting research in general and with reference to intangible disclosures in particular. At the same time, there is a wide range of attributes that might be used to quantify the resource bases of firms measured on the vertical continuum. Taking an overview of the literature these can be generalised into three categories, size related, scope related and complexity related.

\subsection{Hypotheses and Research Design}

Abeysekera \& Guthrie (2005) found that companies with the largest market capitalisation tend to lead the way insofar as the voluntary reporting of IC is concerned; Bozzolan et al. (2003), Garcia-Meca et al. (2005), Garcia-Meca and Martinez (2005) and Guthrie, Petty and Ricceri (2006) confirmed size as a measure of firms' resource base that may lead to the signalling of intangibles. Size appears to be an important explanatory variable whether measured by total assets, sales (Firth, 1979), or market value (Hossain, Tan, \& Adams, 1994; Lang \& Lundholm, 1993). At the one end of the continuum, Ahmed \& Nicholls (1994) argue that larger firms are more likely to have the resources and expertise necessary for the coalition, production and publication of more informative annual reports; similarly, Firth (1979) relates larger firms with the ability to meet the collecting and dissemination costs related to such activities. At the other end of the continuum, smaller firms may restrict full 
disclosure due to competitive costs attributable to larger companies within their industries (Hossain \& Taylor, 2007). Prior empirical research finds a positive association between the scope and complexity of the organisation's activities and disclosure. Scope of activity is measured in terms of SIC codes, which is strongly associated with disclosure (Archambault \& Archambault, 2003; Citron et al., 2005), which earlier studies explain in terms of resource set (Zarzeski, 1996) or increased diversification (Verrecchia, 1983). Operating in several diverse areas or sectors requires the management of a greater amount of information as such firms may increase disclosure in response to the high complexity of operations (Raffournier, 1995; Depoers, 2000). Multiple listing may be indicative of the scope and complexity of organisations activities. Multiple listing may lead to diffusion in ownership concentration as foreign investors acquire equity, agency costs may accumulate as the likelihood of conflicts of interests between shareholders and management increase. Furthermore, due to distance, language and cultural barriers, foreign shareholders are likely to experience higher levels of information asymmetry consistent with the suggestions of Cooke (1998). In this way, multiple listing increases the information disclosed and thus promotes corporate transparency and accountability. Firms with intangible resources have more incentive to disclose IC in order to reduce agency costs (Fama \& Jensen, 1983) related to monitoring. Several empirical studies (Singhvi \& Desai, 1971; Firth, 1979; Cooke, 1992; Hossain et al., 1994; Giner, 1997) have found that firms listed on several stock exchanges provide enhanced disclosures.

Meanwhile Nixon's (1997) conclusions suggest management views disclosure of R\&D expenditure as vital to capital market valuation, suggesting the potential to link the RBV with the signalling approach. Voluntary disclosure of intellectual capital (VDIC) could signal the quality of R\&D activities with higher expected returns particularly where the costs of the signal are negatively correlated with the quality (Seaton \& Walker, 1997). In a study on voluntary disclosure in R\&D industries, Jones (2007) finds that firms disclose a variety of information about all stages of R\&D activity. Generally, disclosures of early and late stage R\&D activity reduce information asymmetry as to how R\&D will translate into sales. Such signals enable the market to identify firm resources that sustain competitive advantage. A significant limitation on any likely relationship between signalling incentives and disclosure is the notion of competitive cost. Competition may restrict full disclosure of intellectual capital (IC) as disclosure may lead to a potential unfavourable change in future earnings (Dye, 1985; Guo, Lev, \& Zhou, 2004). For this reason, the framework in Figure 1 allows for a trade-off between the competitive organisation of the industry, which varies on the vertical axis with the degree of replicability, and the incentives for signalling that too must be reflected in empirical tests. As with the vertical axis of Figure 1, the implied relationships on the horizontal axis have a number of possible measures. The ones that have attracted the most attention in the prior empirical literature are measures of board structure, incentive and involvement, (for example, Haniffa \& Cooke, 2002; Lufti, 1989; Malone et al., 1993) and these are the ones that are also given prominence in this study.

Using Malaysian data, Haniffa and Cooke (2002) found a significant and negative relationship between the presence of a non-executive chair and voluntary disclosure; other board related governance variables including proportion of independent directors and role duality, were insignificant. They concluded that their findings contradict agency theory, indicating the possibility that non-executives must have incentives to keep information private. Forker (1992) argues for example that a dominant personality in a dual role poses a threat to monitoring quality and is detrimental to the quality of disclosure. Eng and Mak (2003) found that a higher proportion of independent non-executive directors to be associated with reduced voluntary disclosure. Haniffa and Cooke (2005) also suggest that non-executives lack the experience and knowledge to promote voluntary disclosure on corporate social responsibility issues. In a study on unlisted companies in the UK, Lufti (1989) reported an insignificant result on the influence of independent directors on voluntary disclosure. Similarly, in the US Malone et al. (1993), reported an insignificant result between mandatory and voluntary disclosure and proportion of outside directors. Reasons for negative effects of non-executive directors more generally may include stifling strategic actions (Goodstein, Gautam, \& Boeker, 1994), excessive monitoring (Baysinger \& Butler, 1985), lack of business knowledge (Patton \& Baker, 1987) and lack of real independence (Demb \& Neubauer, 1992). On the other hand, in line with the predictions of agency theory, Adams and Hossain (1998) and Chen and Jaggi (2000) found empirical evidence of a positive relation between proportion of independent directors and disclosure in Hong Kong. The disclosure attributes differed in these studies, which have used different country contexts and differing levels of mandatory disclosure. In view of the mixed findings in these studies, the relationships would certainly be worth retesting using British data.

For reasons of enhanced executive director power or poor monitoring of their activities, high executive remuneration may be associated with low VDIC. Lufti (1989) identified share option schemes as encouraging voluntary disclosure in UK unlisted companies. However, due to the opportunistic behaviour of directors, agency 
costs may be incurred unless controlled by adequate governance mechanisms (Evans, Evans, \& Loh, 2002). Where the objectives of shareholders and directors are aligned as illustrated by Conyon, Peck and Sadler (2000), directors' compensation may serve as a mechanism to bring about better governance (Ooghe \& De Langhe, 2002) and therefore more accountability and transparency through improved disclosure. Few studies have examined the relationship between intangibles' disclosure and role duality in the chief executive officer and chair. On the one hand, role duality indicates the absence of separation of decision control and decision management (Fama \& Jensen, 1983), on the other, segregation of duties would indicate enhanced control and governance. Finkelstein and D'Aveni (1994) and Gul and Leung (2004) argue that a concentration of decision-making power may mitigate the independence of the board and reduce its effectiveness in its monitoring role. This result is similar to that reported by Forker (1992) in his study of dominant personality and quality of disclosure. Although Gul and Leung (2004) suggest role duality is associated with lower levels of disclosure, this relationship is found to be weaker in the presence of experienced non-executive directors. Similarly, in a study on European Biotechnology companies, Cerbioni and Parbonetti (2007) identified that chief executive officer duality suppresses the disclosure of forward-looking IC information; however, board structure was found to enhance disclosure. Given these prior studies, it appears that good governance structures may mitigate the agency costs that may be attributed to role duality. According to agency theory, combined functions can significantly impair the board's most important functions of monitoring, disciplining and compensating senior managers (Barako, Hancock, \& Izan, 2006); as such, role duality may remove the necessary checks and balances over management behaviour (Blackburn, 1994). The mitigating effect of non-executive directors on this role duality is indicative of the effect of good governance on disclosure levels. Thus, although there has been considerable empirical work examining the relationship between governance and disclosure, it has not been integrated theoretically or tested empirically in conjunction with aspects of the firm's resource base. Tests examining resource attributes have also yielded separate but interesting results. The next section will set out a methodology and model for examining the combined impact of the factors discussed in the review above.

\section{Methodology}

\subsection{Data and Method}

\begin{tabular}{lll}
\hline $\begin{array}{l}\text { Internal } \\
\text { Structural Capital SC (8) }\end{array}$ & External & Human Capital HC (7) \\
\hline 1.Patents & Relational Capital RC (8) & \\
\hline 2.Copyrights & 9.Brands & 17.Know-how \\
\hline 3.Trademarks & 10.Customers & 18.Training \\
\hline 4.Management philosophy & 11.Customer loyalty & 19.Level of education \\
\hline 5.Corporate culture & 12.Distribution channels & 20.Vocational qualifications \\
\hline 6.Management processes & 13.Business collaborations & 21. Staff development \\
\hline 7.Information systems & 14.Licensing agreements & 22.Entrepreneurial spirit \\
\hline 8.Financial relations & 15.Favourable contracts & 23.Innovativeness \\
\hline
\end{tabular}

Figure 2. Intangible attributes

Source: Adapted from Guthrie and Petty (2000)

Sample firms were selected from the FTSE All Share Index for the year 2003/2004 in the Financial Times. Banks, financial, insurance, life assurance, mining, oil and gas, real estate, speciality and other finance and investment and property industries were excluded and every second and third company was selected from the remaining population and their annual reports obtained. This yielded a sample of 460 usable annual reports. A content analysis of the annual reports of sample firms was conducted by adapting the methodologies of Guthrie, Petty, Ferrier and Well (1999), Bozzolan et al. (2003) and Milne and Adler (1999). Following the approach applied by Beattie, McInnes and Fearnley $(2004,32)$, this research splits sentences into text units which are related to intangible attributes. Other visual forms of communication that have been found to provide an immediate and effective means of corporate disclosure (Beattie \& Jones 2001; Beattie \& Thompson 2006; Davison \& Skerratt, 2007) are included. In summary, a voluntary disclosure of an intangible attribute was defined as any text unit, illustration, diagram or graphical presentation that explained the attribute in any part of 
the annual report. All such disclosures are excluded from mandatory disclosure in the Companies Act 1989, EC Directives (Fourth and Seventh), Statement of Standard Accounting Practice, FRS (7, 10 and 11) and the disclosure rules issued by the LSE. It is also necessary to identify a priori intangible attributes. The most common framework originates from Sveiby $(1997,12)$ and was developed by Guthrie $(2001,35)$. Guthrie and Petty (2000), Brennan (2001), April, Bosma and Delgon (2003), Bozzolan et al., (2003) and Guthrie et al., (2004) all applied this framework. For the purposes of comparability with these studies, twenty-three intangible attributes were identified as representative and are illustrated in Figure 2. Milne and Adler (1999) suggest that as the number of content categories increases, the potential for coding errors increases. Conversely, as the number of categories decreases, the likelihood of random agreement in coding decisions increases. Bearing in mind the importance of comparison and replicability, the research defines the 23 intangible attributes as illustrated in Figure 2 as representative of an equilibrium point that ensures limited coding errors and limited random agreement. Agreement levels are assisted by a structured analysis of intangible components following the framework developed by Sveiby (1997) and adapted by Guthrie and Petty (2000). As Figure 2 illustrates, intangibles are accordingly analysed into internal structures (organisational capital), external structures (customer/relational capital) and employee competence (human capital).

\subsection{Research Design}

To ascertain that the scoring was consistent and accurate according to the chosen scoring procedure a verification test was carried out by three researchers from the field in a similar process as that conducted by Guthrie and Petty (2000). Twenty annual reports were randomly selected, scored, compared and correlated. These annual reports were verified and agreed by three independent persons. Explanatory notes on each IC attribute and examples of specific IC disclosures in practice were discussed before the start of the analysis consistent with Bozzolan et al. (2003). The ANOVA test for variance illustrated significantly similar objectivity after 20 annual reports had been coded. The results of the 20 companies pre-tested provided significant evidence of consistency in the coding process. This consistency is important to ensure that each IC attribute in any annual report, is selected if it meets the criteria. The 23 attributes were used to compile a disclosure score (DISC) which is used as a variable in the empirical model below.

\subsection{Model Tested}

The model tested examines the relationship between SCA, governance attributes and disclosure as suggested by Figure 1. The empirical form of the model and a summary of defined variables are set out below. R\&D, SIZE and IND measure the position of the firm on the vertical axis of Figure 1 and the remaining variables the position on the horizontal axis, according to research intensity, scale and scope/complexity respectively. R\&D is defined as the ratio of research and development expenditure to sales revenues, as obtained from Datastream. SIZE is defined as net sales or revenues representing gross sales and other operating revenue less discounts, returns and allowances and is taken from DataStream. IND is a grouping variable ordered by SIC code to reflect broadly increasing complexity, beginning with basic (BASIC), which is used as the reference group, engineering (ENG), electrical (ELEC), pharmaceutical (PHAR), retailers (RET), computer (COMP) and services (SERV). The classification of the sample into these groups is detailed in Figure 3.

\begin{tabular}{|c|l|l|c|}
\hline SIC Code & & Industry & \# of Obs \\
\hline 202 & Basic & Forestry and paper & 2 \\
\hline 1589 & & Food producers and processors & 18 \\
\hline 1596 & & Beverages & 6 \\
\hline 1600 & & Tobacco & 2 \\
\hline 4521 & & Construction and bldg materials. & 34 \\
\hline 2410 & & & 62 \\
\hline 2463 & Chem & Chemicals & 12 \\
\hline 5212 & & Personal care and h'hold prods & 5 \\
\hline & & Household goods and textiles & 14 \\
\hline 2840 & & & 31 \\
\hline 2710 & Eng & Steel and other & 2 \\
\hline 3430 & & Engineering and machinery & 24 \\
\hline 3530 & & Automobiles and parts & 10 \\
\hline 3002 & & Aerospace and Defence & 7 \\
\hline
\end{tabular}




\begin{tabular}{|c|l|l|c|}
\hline 3210 & & Electronic and electrical equip't & 16 \\
\hline 4013 & & Electricity & 3 \\
\hline 4100 & & Utilities (Ex-electricity & 8 \\
\hline 5147 & & Diversified industries & 6 \\
\hline 2441 & & & 50 \\
\hline & Phar & Pharmaceuticals and biotech & 14 \\
\hline 5211 & & & 14 \\
\hline 5211 & Ret & General retailers & 35 \\
\hline & & Food and drug retailers & 6 \\
\hline 7222 & & & 41 \\
\hline 7412 & Comp & Software and computer services & 31 \\
\hline 7420 & & Support services & 59 \\
\hline 7440 & & Telecommunication services & 12 \\
\hline 6340 & & Media and entertainment & 39 \\
\hline 8511 & & & 141 \\
\hline 9210 & Serv & Transport & 22 \\
\hline & & Health & 14 \\
\hline
\end{tabular}

Figure 3. Sample classification by industry and SIC code

Multiple listing (MLTL) represents companies listed on more than one stock exchange and is obtained from the annual report. NONEXEC is the ratio of non-executive directors to total directors and is obtained from the annual report, as is EXECREM, the ratio of executive remuneration to market value. DUALITY combines the dual roles of chief executive officer and company chair; this variable is measured by a dichotomous variable and is obtained from the annual report, as is CNED that represents a non-executive chair.

$$
\begin{gathered}
D I S C=\beta_{0}+\beta_{1} R \& D+\beta_{2} S I Z E+\beta_{3} I N D+\beta_{4} M L T L+\beta_{5} N O N E X E C+ \\
\beta_{6} E X E C R E M+\beta_{7} D U A L I T Y+\beta_{8} C N E D+\varepsilon
\end{gathered}
$$

where: $\beta_{0} \quad:$ intercept;

$\beta_{1-} \beta_{8} \quad: \quad$ coefficient of slope parameters;

$\varepsilon \quad: \quad$ error term.

\subsection{Research Design}

Descriptive statistics for variables included in equations (1) are set out in Table 1. Panel A of Table 1 presents descriptive statistics and correlation matrix for continuous variables; correlations above the diagonal illustrate the cross-correlations between non-continuous governance variables. Panel B of Table 1 presents descriptive statistics on the determinants of disclosure by industry and Panel $\mathrm{C}$ of Table 1 by governance dummy variable. The statistics in Table 1 Panel A indicate significant cross-correlations in the governance variables, suggesting that these might be substitutes for modelling purposes, and similarly between industry and R\&D intensity.

\section{Results}

\subsection{Descriptive Statistics}

\begin{tabular}{|c|c|c|c|c|c|c|c|c|c|c|}
\hline Variable & Mean & $\begin{array}{l}\text { Standard } \\
\text { deviation }\end{array}$ & A & B & $\mathrm{C}$ & $\mathrm{D}$ & $\mathrm{E}$ & $\mathrm{F}$ & G & $\mathrm{H}$ \\
\hline A DISC & 0.561 & 0.118 & 1 & & & & & $0.211^{* * *}$ & -0.011 & -0.118 \\
\hline B SIZE & 5.811 & 2.013 & $0.278 * * *$ & 1 & & & & $0.449 * * *$ & 0.005 & -0.101 \\
\hline C R\&D & 0.044 & 0.240 & $0.085^{*}$ & $-0.234 * * *$ & 1 & & & $0.188^{* * *}$ & 0.026 & -0.019 \\
\hline D NONEXEC & 0.490 & 0.177 & 0.052 & 0.013 & 0.044 & 1 & & 0.089 & $-0.194 * * *$ & $0.366^{* * *}$ \\
\hline E EXCREM & 1864.480 & 2321.618 & $0.236 * * *$ & $0.502 * * *$ & -0.065 & $0.145^{* * *}$ & 1 & $0.186^{* * *}$ & $-0.155^{* *}$ & 0.018 \\
\hline F MLTL & 0.200 & 0.401 & $0.215^{* * *}$ & $0.481 * * *$ & -0.008 & -0.037 & $0.331 * * *$ & 1 & 0.094 & $-0.158 * *$ \\
\hline G DUALITY & 0.112 & 0.315 & & & & & & & 1 & $-0.298 * * *$ \\
\hline H CNED & 0.522 & 0.500 & & & & & & & & 1 \\
\hline
\end{tabular}

Table 1 Panel A. Descriptive statistics and correlation matrix for continuous variables 
The descriptive statistics indicate that larger companies are more likely to list on multiple exchanges; in addition, these firms generally compensate their executives with higher rates of pay. It is therefore not surprising that an association exists between disclosure and executive remuneration and disclosure and multiple listing due to the correlation attributed to the size variable.

In contrast, $R \& D$ is found to be more concentrated in relatively smaller firms, given that this ratio decreases with increasing size as represented by turnover. The significant cross-correlations in the governance variables indicate that executive officers receive significantly more compensation in the presence of experienced non-executive directors. Whether non-executives are motivated by the need to match or better market rates or whether this is an indication of ineffective governance measures remains to be investigated. Nevertheless, the statistics indicate that multiple listed companies are more likely to provide better remuneration to their directors; however, given that multiple listed firms are generally large companies, it may be that this association is attributed to size. The Spearman co-efficients which are used for the grouping variables in Table 1 Panel A, reflect the significant association between multiple listing and size in the positive association of this listing status with intangibles disclosure and with executive remuneration. The relationship between R\&D intensity and multiple listing is not reflected in the Pearson co-efficients, which are used for continuous variables, particularly as the relationship with size is negative. It appears therefore that $R \& D$ is more closely associated with multiple listing than it is with size. There is therefore an expectation that smaller multiple listed companies are associated with R\&D intensity. Experienced non-executive directors support the segregation of decision-making and decision-management, preferring to spread decision making-power; as such, the dual role of chair and chief executive officer is not often found where these governance mechanisms exist. Furthermore, as this role duality suppresses executive remuneration, and as experienced non-executive directors appear to be aligned to directors interests in as far as compensation is concerned, it may be expected that experienced non-executive directors may not favour the appointments of a combined chair and chief executive. Of additional interest is the favourable interaction between experienced non-executive directors and the appointment of a chair who is a non-executive director that may be attributed to the alignment of non-executive agendas. However, it is more likely that non-executive chairs favour boards that have a significant number of experienced non-executive directors. Nevertheless, such non-executive chairs are not common amongst multiple listed companies nor are they found in firms in which a dual role exists between the chair and the chief executive.

Table 1 Panel B. Descriptive statistics by industry

\begin{tabular}{cccccccc}
\hline Industry Group & R\&D & SIZE & EXECREM & NONEXEC & DUALITY & CNED & MLTL \\
\hline Mean & & & & & & & \\
BASIC & 0.003 & 6.481 & 0.490 & 2292.469 & 0.065 & 0.629 & 0.210 \\
CHEM & 0.015 & 5.936 & 0.544 & 2154.764 & 0.080 & 0.600 & 0.280 \\
ENG & 0.017 & 6.529 & 0.436 & 1526.328 & 0.186 & 0.558 & 0.256 \\
ELEC & 0.096 & 5.777 & 0.496 & 1620.832 & 0.100 & 0.380 & 0.300 \\
PHAR & 0.708 & 5.126 & 0.518 & 1629.219 & 0.000 & 0.615 & 0.538 \\
RET & 0.006 & 6.043 & 0.497 & 1694.411 & 0.170 & 0.426 & 0.106 \\
COMP & 0.025 & 5.231 & 0.493 & 1993.988 & 0.106 & 0.504 & 0.142 \\
SERV & 0.007 & 5.915 & 0.483 & 1618.296 & 0.121 & 0.569 & 0.172 \\
Standard Dev & & & & & & 0.49 \\
BASIC & 0.007 & 1.749 & 0.147 & 1787.529 & 0.248 & 0.487 & 0.410 \\
CHEM & 0.020 & 1.930 & 0.196 & 3101.887 & 0.277 & 0.500 & 0.458 \\
ENG & 0.017 & 1.979 & 0.210 & 1335.894 & 0.394 & 0.502 & 0.441 \\
ELEC & 0.178 & 2.447 & 0.230 & 2725.804 & 0.303 & 0.490 & 0.463 \\
PHAR & 1.187 & 3.032 & 0.263 & 1791.161 & 0.000 & 0.506 & 0.519 \\
RET & 0.018 & 1.934 & 0.145 & 1343.355 & 0.380 & 0.500 & 0.312 \\
COMP & 0.064 & 1.855 & 0.149 & 2895.665 & 0.309 & 0.502 & 0.350 \\
SERV & 0.018 & 1.729 & 0.182 & 1733.180 & 0.329 & 0.500 & 0.381 \\
\hline
\end{tabular}

Panel B of Table 1 indicates the variation in descriptive statistics by industry. The results provide further support that R\&D intensity may be a substitute for industry group given that BASIC industries are the least R\&D intensive and PHAR industries highly R\&D intensive. The results support the premise that R\&D intensive firms disclose more intangibles; although these firms are generally smaller they are nevertheless multiple listed. Governance mechanisms ensure that an acceptable number of experienced non-executive directors are appointed 
in these firms and that executives are adequately compensated. Although such firms as those found in PHAR industries support the existence of a non-executive chair, none of these companies is chaired by their chief executive. In contrast, firms in BASIC industries are very large and are less likely to list on an additional exchange.

Table 1 Panel C. Descriptive statistics by governance dummy variable

\begin{tabular}{lrr}
\hline Variable & DUALITY & CNED \\
\hline Mean & & \\
DISC & 0.558 & 0.547 \\
SIZE & 5.986 & 5.578 \\
NONEXEC & 0.366 & 0.549 \\
EXCREM & 1848.740 & 1721.993 \\
Standard deviation & & \\
DISC & 0.130 & 0.118 \\
SIZE & 2.700 & 1.806 \\
NONEXEC & 0.230 & 0.122 \\
EXCREM & 4268.706 & 1625.473 \\
\hline
\end{tabular}

Notes: $* * * p$-value $<0.01 ; * * p$-value $<0.05 ; * p$-value $<0.10$; Pearson's coefficients reported for pairs of continuous variables and Spearman for pairings involving dichotomous variables.

Moreover, these firms generally have less well-paid executives; this may be consistent with the existence of the highest concentration of experienced non-executives and highest number of non-executive chairs for any industry. These relationships are generally reflected in industries of similar R\&D intensity. BASIC industries are associated with RET and SERV industries whereas the characteristics of PHAR industries are found in ELEC and COMP industries. In Panel C of Table 1, the results illustrate that duality in the chair and chief executive promotes intangibles disclosure, accountability and transparency marginally more than the duality in the non-executive chair. Firms that appoint a dual chair and chief executive officer are larger than those appointing a non-executive chair; these firms employ less experienced non-executive directors as a result it appears that executives in these firms receive slightly less compensation. These relationships are borne in mind for the purpose of specifying and reporting the results of the inferential models below.

\subsection{Regression Analysis}

This section reports the results of the relation between disclosure, heterogeneous firm resources and governance characteristics. Table 2 presents the results of the inferential models; Models 1 to 7 present the results using non-parametric quantile regression (QREG), since ordinary least squares (OLS) model residuals demonstrated non-normal characteristics. Models 8 and 9 report results for selected OLS specifications using heteroscedasticity adjusted standard errors, as these demonstrate normal characteristics and are therefore presented in Table 2 for reference and comparison.

Table 2. Model (1) regression results

\begin{tabular}{|c|c|c|c|c|c|c|c|c|c|}
\hline Model & 1 & 2 & 3 & 4 & 5 & 6 & 7 & 8 & 9 \\
\hline $\begin{array}{l}\text { Dependent variable } \\
\text { Independent variables }\end{array}$ & DISC & DISC & DISC & DISC & DISC & DISC & DISC & DISC & DISC \\
\hline CONSTANT & $\begin{array}{c}0.564 * * * \\
(12.52)\end{array}$ & $\begin{array}{c}0.452 * * * \\
(19.14)\end{array}$ & $\begin{array}{c}0.319^{* * *} \\
(9.00)\end{array}$ & $\begin{array}{c}0.320^{* * *} \\
(9.47)\end{array}$ & $\begin{array}{c}0.304 * * * \\
(7.04)\end{array}$ & $\begin{array}{c}0.566^{* * *} \\
(11.61)\end{array}$ & $\begin{array}{c}0.310^{* * * *} \\
(8.78)\end{array}$ & $\begin{array}{c}0.346^{* * *} \\
(14.50)\end{array}$ & $\begin{array}{c}0.352^{* * *} \\
(12.04)\end{array}$ \\
\hline$R \& D$ & $\begin{array}{l}0.177 \\
(0.78)\end{array}$ & $\begin{array}{c}0.079 * * \\
(2.49)\end{array}$ & & & & & $\begin{array}{l}0.013 \\
(0.67)\end{array}$ & $\begin{array}{r}0.030^{*} \\
(1.71)\end{array}$ & \\
\hline MLTL & & & $\begin{array}{l}0.017 \\
(1.00)\end{array}$ & $\begin{array}{l}0.017 \\
(1.03)\end{array}$ & $\begin{array}{l}0.016 \\
(0.75)\end{array}$ & & $\begin{array}{l}0.010 \\
(0.56)\end{array}$ & & $\begin{array}{l}0.012 \\
(0.09)\end{array}$ \\
\hline NONEXEC & & & $\begin{array}{c}0.059 * \\
(1.68)\end{array}$ & $\begin{array}{c}0.059^{*} \\
(1.72)\end{array}$ & $\begin{array}{l}0.035 \\
(0.86)\end{array}$ & $\begin{array}{l}0.059 \\
(1.33)\end{array}$ & $\begin{array}{c}0.062 * \\
(1.85)\end{array}$ & & $\begin{array}{l}0.034 \\
(1.17)\end{array}$ \\
\hline EXECREM & & & $\begin{array}{l}0.000 \\
(1.33)\end{array}$ & $\begin{array}{l}0.000 \\
(0.95)\end{array}$ & $\begin{array}{l}0.000 \\
(1.25)\end{array}$ & $\begin{array}{l}0.000 \\
(0.62)\end{array}$ & $\begin{array}{l}0.000 \\
(0.88)\end{array}$ & & $\begin{array}{l}0.000 \\
(1.07)\end{array}$ \\
\hline DUALITY & & & $\begin{array}{l}0.009 \\
(0.48)\end{array}$ & & $\begin{array}{l}0.022 \\
(0.98)\end{array}$ & $\begin{array}{l}0.009 \\
(0.38)\end{array}$ & $\begin{array}{l}0.006 \\
(0.32)\end{array}$ & & $\begin{array}{l}-0.001 \\
(-0.03)\end{array}$ \\
\hline CNED & & & $\begin{array}{l}-0.022 * \\
(-1.72)\end{array}$ & $\begin{array}{c}-0.022^{*} \\
(-1.79)\end{array}$ & & $\begin{array}{l}-0.020 \\
(-1.24)\end{array}$ & $\begin{array}{c}-0.023^{*} \\
(-1.75)\end{array}$ & & $\begin{array}{l}0.018 * \\
(-1.72)\end{array}$ \\
\hline
\end{tabular}




\begin{tabular}{|c|c|c|c|c|c|c|c|c|c|}
\hline SIZE & $\begin{array}{c}0.026^{* * *} \\
(8.15)\end{array}$ & $\begin{array}{c}0.018 * * * \\
(4.75)\end{array}$ & $\begin{array}{c}0.018^{* * *} \\
(4.80)\end{array}$ & $\begin{array}{c}0.019 * * * \\
(5.20)\end{array}$ & $\begin{array}{c}0.019 * * * \\
(4.29)\end{array}$ & $\begin{array}{c}0.021 * * * \\
(5.03)\end{array}$ & $\begin{array}{c}0.020^{* * * *} \\
(5.26)\end{array}$ & $\begin{array}{c}0.024 * * * \\
(10.06)\end{array}$ & $\begin{array}{c}0.021 * * * \\
(6.61)\end{array}$ \\
\hline CHEM & $\begin{array}{c}-0.269 * * * \\
(-5.80)\end{array}$ & & & & & $\begin{array}{c}-0.261 * * * \\
(-5.36)\end{array}$ & & & \\
\hline ENG & $\begin{array}{c}-0.245^{* * *} \\
(-5.64)\end{array}$ & & $\begin{array}{l}0.019 \\
(0.63)\end{array}$ & $\begin{array}{l}0.015 \\
(0.51)\end{array}$ & $\begin{array}{l}0.033 \\
(0.90)\end{array}$ & $\begin{array}{c}-0.242 * * * \\
(-5.35)\end{array}$ & $\begin{array}{l}0.018 \\
(0.59)\end{array}$ & $\begin{array}{l}-0.012 \\
(-0.52)\end{array}$ & $\begin{array}{l}-0.005 \\
(-0.23)\end{array}$ \\
\hline ELEC & $\begin{array}{c}-0.131 * * * \\
(-3.10)\end{array}$ & & $\begin{array}{c}0.145 * * * \\
(4.95)\end{array}$ & $\begin{array}{c}0.133 * * * \\
(4.70)\end{array}$ & $\begin{array}{c}0.155^{* * *} \\
(4.41)\end{array}$ & $\begin{array}{c}-0.122 * * * \\
(2.76)\end{array}$ & $\begin{array}{c}0.138 * * * \\
(4.68)\end{array}$ & $\begin{array}{c}0.109^{* * * *} \\
(4.35)\end{array}$ & $\begin{array}{c}0.110 * * * \\
(4.40)\end{array}$ \\
\hline PHARM & & & $\begin{array}{c}0.251^{* * *} \\
(6.20)\end{array}$ & $\begin{array}{c}0.249 * * * \\
(6.34)\end{array}$ & $\begin{array}{c}0.264 * * * \\
(5.34)\end{array}$ & & $\begin{array}{c}0.249 * * * \\
(5.62)\end{array}$ & $\begin{array}{c}0.211 * * * \\
(7.97)\end{array}$ & $\begin{array}{c}0.231 * * * \\
(9.91)\end{array}$ \\
\hline RETAIL & $\begin{array}{c}-0.248 * * * \\
(-5.74)\end{array}$ & & $\begin{array}{l}0.018 \\
(0.60)\end{array}$ & $\begin{array}{l}0.016 \\
(0.55)\end{array}$ & $\begin{array}{l}0.026 \\
(0.74)\end{array}$ & $\begin{array}{c}-0.242^{* * *} \\
(-5.46)\end{array}$ & $\begin{array}{l}0.020 \\
(0.66)\end{array}$ & $\begin{array}{l}0.004 \\
(0.15)\end{array}$ & $\begin{array}{l}0.004 \\
(0.16)\end{array}$ \\
\hline COMP & $\begin{array}{c}-0.101 * * \\
(-2.49)\end{array}$ & & $\begin{array}{c}0.160^{* * *} \\
(6.15)\end{array}$ & $\begin{array}{c}0.159^{* * *} \\
(6.37)\end{array}$ & $\begin{array}{c}0.166^{* * *} \\
(5.25)\end{array}$ & $\begin{array}{c}-0.100^{* *} \\
(-2.46)\end{array}$ & $\begin{array}{c}0.159 * * * \\
(6.06)\end{array}$ & $\begin{array}{c}0.128^{* * *} \\
(6.28)\end{array}$ & $\begin{array}{c}0.127 * * * \\
(6.27)\end{array}$ \\
\hline SERV & $\begin{array}{c}-0.115 * * * \\
(-2.70)\end{array}$ & & $\begin{array}{c}0.145^{* * * *} \\
(5.08)\end{array}$ & $\begin{array}{c}0.141 * * * \\
(5.15)\end{array}$ & $\begin{array}{c}0.155^{* * *} \\
(4.46)\end{array}$ & $\begin{array}{c}-0.115^{* * *} \\
(2.65)\end{array}$ & $\begin{array}{c}0.145^{* * * *} \\
(5.04)\end{array}$ & $\begin{array}{c}0.115^{* * *} \\
(5.17)\end{array}$ & $\begin{array}{c}0.118 * * * \\
(5.40)\end{array}$ \\
\hline $\begin{array}{c}\text { Shapiro-Wilk p-value } \\
\text { F }\end{array}$ & & & & & & & & $\begin{array}{c}0.607 \\
34.64 * * *\end{array}$ & $\begin{array}{c}0.614 \\
27.36^{* * *}\end{array}$ \\
\hline Adj $R^{2}$ & 0.224 & 0.046 & 0.232 & 0.232 & 0.229 & 0.231 & 0.233 & 0.367 & 0.373 \\
\hline $\mathrm{N}$ & 439 & 439 & 439 & 439 & 439 & 439 & 439 & 439 & 439 \\
\hline
\end{tabular}

Notes:

Numbers in parentheses are t-statistics based on White's (1980) heteroscedasticity consistent estimation matrix.Significance levels (one-tailed test except intercept terms and industry dummies):

$* * * \mathrm{p}<.01 ; * * \quad \mathrm{p}<.05 ; * \mathrm{p}<.10$

Table 2 reports Shapiro-Wilk test results for residual normality in these models. The interaction between intangibles disclosure and the heterogeneous asset base is examined in Models 1, 2 and 8; that with governance mechanisms in Models 3, 4, 5, 6 and 9; and the combined interaction between disclosure, heterogeneous firm resources and governance characteristics in Model 7. Consistent with Abeysekera \& Guthrie (2005) and Garcia-Meca \& Martinez (2005), the results of all inferential models confirm that large firms' that possess imitable and unique intangible assets are able to signal SCA. In Model 2, although providing a lower explanatory factor in the QREG model relative to other inferential models, the results of Model 8, the OLS model do indicate a positive influence of R\&D activities on intangibles disclosure. The interaction between the scope and complexity of the organisation's activities and disclosure are examined by both the industry dummies and the investment in R\&D. Models 1 and 2 indicate that R\&D intensity may be a substitute for industry complexity and may as suggested by Nixon (1997), be linked to the RBV with the signalling approach. Firms in such industries as PHARM, ELEC and COMP may be prejudiced by the current reporting regime that is unable to account for the complex nature of intangible resources. To increase and sustain value to shareholders, the onus is on management to signal SCA through intangibles disclosure; such signals enhance transparency and accountability, reduce information asymmetry and are not likely to accrue proprietary costs. The lack of competitive losses associated with such disclosures has been attributed to the unique nature of intangibles.

Model 3 to 7 and Model 9 present the interaction between the heterogeneous asset base and the firm's corporate governance mechanisms and structures of accountability. Industry dummies control for the existence of intangibles resources as represented by complexity in operations; governance mechanisms, experienced non-executive directors and the separation of the dual role of non-executive chair promote intangibles disclosure as presented by the results of Models 3, 4 and 7. However, the influence of experienced non-executive directors is limited when the dual role is not in place as illustrated by Model 5. Model 4 indicates little variation in disclosure whether firms combine the roles of chief executive officer and chair or not; other governance measures effect on disclosure however is influenced by the presence or absence of complimentary structures. Models 3, 4 and 7 illustrate this finding; within firms that are multiple listed, non-executive chairs and experienced non-executive directors are significantly more influential in promoting intangibles disclosure than in companies with one listing status. The increase in reporting requirements due to multiple listing appears evident here, however where these multiple listed companies do not appoint a non-executive chair, experienced non-executive directors become ineffective in ensuring accountability and transparency through disclosure. The results support the analysis based on the descriptive statistic reported in section 3.1 above as it appears governance mechanisms are more effective when working in cooperation. 
Individually, other board related governance variables including role duality in the chief executive officer and chair, multiple listing and executive remuneration are insignificant in influencing the signalling of intangibles as illustrated by Model 3 to 7 and by Model 9. The results illustrate that experienced non-executive directors promote transparency and accountability, although this relationship is found to be weak as illustrated by Model 9 . The effectiveness of this role is dependent on the chair being an executive director and further that firms have supporting governance structures modelled on multiple listed companies. Such structures where roles and responsibilities are separated allow experienced non-executive directors to compliment the existing governance mechanisms in enhancing VDIC particularly where the resource base is non-replicable. Thus, the absence of the separation of decision control and decision management (Fama \& Jensen, 1983) leads to a lack of transparency and accountability. Furthermore, a concentration of decision-making power may mitigate the independence of the board and reduce its effectiveness in its monitoring role. The results are consistent with the findings of Cerbioni and Parbonetti (2007) who identified that chief executive officer duality suppresses the disclosure of forward-looking IC information. Directors' compensation has been associated with reduced agency costs; however, the results do not provide evidence for this hypothesis. The theoretical basis for linking executive remuneration with intangible disclosure levels has not been confirmed in contrast to Lufti (1989), where executive remuneration is insignificant in explaining the variation in intangibles disclosure. Directors' compensation is therefore insufficient in influencing management into better governance (Ooghe \& De Langhe, 2002).

Although some prior studies have confirmed multiple listing as significant in disclosure studies, the results indicate that VDIC may be independent of the number of listings a firm may have. As multiple listing may expand both the diversity and the operating sectors of a firm, it may promote transparency and accountability in reducing asymmetric information. Furthermore, additional disclosures may be required to account for the increase in the complexity of operations. Nevertheless, the results of all models indicate that the incremental reporting requirements and additional governance measures attributed to a foreign listing may not have a direct impact on the signalling of intangibles. Overall, the QREG models report results that are consistent with those of the robust OLS models.

\section{Discussion}

This paper examines the determinants of the disclosure of intangibles, specifically the interaction of heterogeneous assets and governance mechanisms on disclosure. As a measure of disclosure, each firm was allocated a disclosure score based on 23 IC attributes. The regression results show that size as a measure of scope, R\&D intensity as a measure of complexity of operating activities, and the separation of the roles of chair and non-executive director, complimented by the existence of experienced non-executive directors as governance mechanisms, support the analytical and theoretical framework as illustrated in Figure 1. Industry dummy variables illustrate the variation in the signalling of intangibles with increasing complexity of operations and R\&D intensity. Overall, the results are consistent with the separate effects of resource attributes on the disclosure of intangible assets (Archambault \& Archambault, 2003; Citron et al., 2005) and with the role of such disclosures as signals (Bozzolan et al., 2003; Garcia-Meca et al., 2005). The results suggest that the influence of board composition on disclosure supports the hypothesis that governance mechanisms enhance accountability and transparency (Haniffa \& Cooke, 2002; Lufti, 1989; Malone et al., 1993).

The results indicate that investment in intangible resources and their disclosure through transparent governance structures are potential mechanisms to secure competitive advantage. These governance structures have been seen to be more effective when not in conflict as such the mere presence of intangible resources may not be a sufficient condition for their disclosure in the annual report. Governance mechanisms that encourage the separation of dual roles and support the appointment of experienced non-executive directors promote transparency and accountability.

Industry dummies and R\&D intensity illustrate that those technological and innovative industries, that posses valuable, rare, inimitable and non-substitutable assets, are able to sustain their competitive advantage through intangibles disclosure (Barney, 1991). These intangible assets are found in firms operating in highly complex and $R \& D$ intensive industries that may be prejudiced by the current reporting practice that lacks adequate procedures to identify, organise and manage investment in intangibles such as R\&D development costs. These firms have been found to be highly technological and innovative and therefore linked to non-manufacturing and/or service industries. Other characteristics that have been attributed to these firms include being IA intensive, having economies of scale, having minimal or zero marginal cost as most services are outsourced. The results indicate that PHARM, ELEC and COMP are industries that fall under this category. 
The current paper is the first to study intangibles disclosure by examining the interaction of firm resources, corporate governance and intangibles disclosure within a RBV and signalling theoretical framework. Effective corporate governance mechanisms enhance transparency and accountability for firms undertaking highly complex operations. This is especially so for firms that possess VRIN intangibles, assets that are not easily imitated and as such do not accrue proprietary costs on disclosure. There may be a potential benefit in future research on temporal links between IC value drivers and IC performance; future research may also investigate how disclosure of SCA influences the market and financial risk attributed to firms.

\section{Acknowledgements}

I am indebted to Professor S. Toms, my PhD supervisor and mentor, for useful comments, criticisms and suggestions on an earlier draft.

\section{References}

Abeysekera, I., \& Guthrie, J. (2005). An empirical investigation of the annual reporting trends of intellectual capital in Sri Lanka. Critical Perspectives on Accounting, 16, 151-163. http://dx.doi.org/10.1016/S1045-2354(03)00059-5

Adams, M., \& Hossain, M. (1998). Managerial discretion and voluntary disclosure: Empirical evidence from the New Zealand life insurance industry. Journal of Accounting and Public Policy, 17, 245-281. http://dx.doi.org/10.1016/s0278-4254(98)10003-0

Ahmed, K., \& Nicholls, D. (1994). The impact of non-financial company characteristics on mandatory compliance in developing countries: the case of Bangladesh. The International Journal of Accounting: Education and Research, 29(1), 60-77. http://dx.doi.org/10.1111/j.1539-6975.2010.01399.x

Akerlof, G. A. (1970). The market for "lemons": quality uncertainty and the market mechanism. Journal of Economics, 84(3), 488-500. http://dx.doi.org/10.4337/9781781950005.00012

Amit, R., \& Schoemaker, P. J. H. (1993). Strategic assets and organisational rents. Strategic Management Journal, 14(1), 33-46. http://dx.doi.org/10.1002/smj.4250140105

April, K. A., Bosma, P. A., \& Delgon, D. A. (2003). Intellectual Capital measurement and reporting: Establishing a practice in SA mining. Journal of Intellectual Capital, 4(2), 165-180. http://dx.doi.org/10.1108/14691 930310472794

Archambault, J. J., \& Archambault, M. E. (2003). A multinational test of determinants of corporate disclosure. The International Journal of Accounting, 38(2), 173-194. http://dx.doi.org/10.1016/S0020-7063(03) 00021-9

Barako, D. G., Hancock, P., \& Izan, H. Y. (2006). Factors influencing voluntary corporate disclosure by Kenyan companies. Corporate Governance, 14(2), 107-125. http://dx.doi.org/10.1111/j.1467-8683.2006.00491.x

Barney, J. B. (1991). Firm resources and sustained competitive advantage. Journal of Management, 17(1), 99-120. http://dx.doi.org/10.1177/014920639101700108

Baysinger, B. D., \& Butler, H. N. (1985). Corporate governance and the board of directors: performance effects of changes in board composition. Journal of Law Economics and Organisations, 1(1), 101-125. Retrieved from http://www.jstor.org/stable/764908

Beattie, V., \& Jones, M. A. (2001). A six-country comparison of the use of graphs in annual reports. International Journal of Accounting, 36(2), 195-222. http://dx.doi.org/10.1016/s0020-7063(01)00094-2

Beattie, V., \& Thompson, S. J. (2006). Lifting the lid on the use of content analysis to investigate intellectual capital disclosures. Edinburg: School on Management and Languages, Herriot-Watt. http://dx.doi.org/10. 1016/j.accfor.2007.02.001

Beattie, V., Mcinnes, W., \&Fearnley, S. (2004).Through the eyes of management narrative reporting across three sectors. London: Institute of Chartered Accountants of England and Wales. http://dx.doi.org/10.1016/s08908389(03)00021-0

Blackburn, V. (1994). The effectiveness of corporate control in the US corporations. Corporate Governance: An International Review, 2(4), 196-202. http://dx.doi.org/10.1111/j.1467-8683.1994.tb00078.x

Bozzolan, S., Favotto, F., \& Ricceri, F. (2003). Italian annual intellectual capital disclosure: An empirical analysis. Journal of Intellectual Capital, 4(4), 543-558. http://dx.doi.org/10.1108/14691930310504554

Brennan, N. (2001). Reporting intellectual capital in annual reports: Evidence from Ireland. Accounting, 
Auditing \& Accountability Journal, 14(4), 423-436. http://dx.doi.org/10.1108/09513570110403443

Cerbioni, F., \& Parbonetti, A. (2007). Exploring the effects of corporate governance on intellectual capital disclosure: an analysis of European biotechnology companies. European Accounting Review, 16(4), 791-826. http://dx.doi.org/10.1080/09638180701707011

Chen, C. J. P., \& Jaggi, B. (2000). Association between independent non-executive directors, family control and financial disclosures in Hong Kong. Journal of Accounting and Public Policy, 19(4/5), 285-310. http://dx.doi.org/10.1016/s0278-4254(00)00015-6

Cheng, E., \& Courtenay, S. (2006). Board composition, regulatory regime and voluntary disclosure. International Journal of Accounting, 41(3), 262-289. http://dx.doi.org/10.1016/j.intacc.2006.07.001

Citron, D., Holden, J., Selim, G., \& Oehlcke, F. (2005). Do voluntary intellectual capital disclsoure provide information about firms' intangible assets? Financial Reporting and Business Communication conference. 7 \& 8 July 2005, (Working paper) Cardiff Business School, London. http://dx.doi.org/10.1016/j. accfor.2005.10.001

Coff, R. W. (1997). Human assets and management dilemmas: Coping with hazards on the road to resource-based theory. Academy of Management Review, 22(2), 374-402. http://dx.doi.org/10.5465/amr. 1997.9707154063

Conyon, M. J., Peck, S. I., \& Sadler, G. (2000). Econometric Modelling of UK Executive Compensation. Managerial Finance, 26(9), 3-20. http://dx.doi.org/10.1108/03074350010766846

Cooke, T. E. (1992). The impact of size, stock market listing and industry type on disclosure in the annual reports of Japanese listed corporations. Accounting and Business Research, 22(87), 229-237. http://dx.doi.org/10.1080/00014788.1992.9729440

Cooke, T. E. (1998). Regression analysis in accounting disclosure studies. Accounting and Business Research 28(3), 209-224. http://dx.doi.org/10.1080/00014788.1998.9728910

Davison, J., \& Skerratt, L. (2007). Words, pictures and intangibles in the corporate report. Edinburg: The Institute of Chartered Accountants of Scotland.

Demba, A., \& Neubauer, F. F. (1992). The corporate board: confronting the paradoxes. Oxford University Press. http://dx.doi.org/10.1002/jsc.4240020313

Depoers, F. (2000). A cost-benefit study of voluntary disclosure: some empirical evidence from French listed companies. European Accounting Review, 9(2), 245-263. http://dx.doi.org/10.1080/09638180050129891

Dierickx, I., \& Cool, K. (1989). Asset stock accumulation and sustainability of competitive advantage. Management Science, 35(12), 1504-1511. http://dx.doi.org/10.1287/mnsc.35.12.1504

Dye, R. A. (1985). Disclosure of non-proprietary information. Journal of Accounting Research, 23(1), 123-145. http://dx.doi.org/10.2307/2490910

Eng, L., \& Mak, Y. (2003). Corporate governance and voluntary disclosure. Journal of Accounting and Public Policy, 22(4), 325-345. http://dx.doi.org/10.1016/s0278-4254(03)00037-1

Evans, J., Evans, R., \& Loh, S. (2002). Corporate governance and declining performance. International Journal of Business Studies, 10(1), 1-18. Retrieved from http://espace.library.curtin.edu.au:80/R?func=dbin-jumpfull\&local_base $=$ gen01-era02\&object_id $=20965$

Fama, E. F., \& Jensen, M. C. (1983). Separation of ownership and control. The Journal of Law and Economics, 26(2), 301-325. http://dx.doi.org/10.2139/ssrn.94034

Finkelstein, S., \& D'Aveni, R. A. (1994). CEO duality as a double-edged sword: How boards of directors balance entrenchment avoidance and unity of command. Academy of Management Journal, 37(5), 1079-1108. http://dx.doi.org/10.2307/256667

Firth, M. A. (1979). The Impact of size, stock market listing and auditors on voluntary disclosure in corporate annual reports. Accounting and Business Research, 9(36), 273-280. http://dx.doi.org/10.1080/00014788. 1979.9729168

Forker, J. J. (1992). Corporate governance and disclosure quality. Accounting and Business Research, 22(86), 111-124. http://dx.doi.org/10.1080/00014788.1992.9729426

Garcia-Meca, E., \& Martinez, I. (2005).Assessing the quality of disclosure on intangibles in the Spanish capital market. European Business Review, 17(4), 305-313. http://dx.doi.org/10.1108/09555340510607352 
Garcia-Meca, E., Parra, I., Martinez, I., \& Larran, M. (2005). The explanatory factors of intellectual capital disclosure to financial analysts. European Accounting Review, 14(1), 63-94. http://dx.doi.org/10.1080/ 0963818042000279713

Goodstein, J., Gautam, K., \& Boeker, W. (1994). The effect of board size and diversity on strategic change. Strategic Management Journal, 15(3), 241-250. http://dx.doi.org/10.1002/smj.4250150305

Grant, R. (1996). Toward a knowledge-based theory of the firm. Strategic Management Journal, 17, 109-122. http://dx.doi.org/10.1002/smj.4250171110

Gul, F., \& Leung, S. (2004). Board leadership, outside directors' expertise and voluntary corporate disclosures. Journal of Accounting \& Public Policy, 23(5), 351. http://dx.doi.org/10.1016/j.jaccpubpol.2004.07.001

Guo, R.-J., Lev, B., \& Zhou, N. (2004). Competitive cost of disclosure by biotech IPOs. The Journal of Accounting Research, 42(2), 319-355. http://dx.doi.org/10.1111/j.1475-679x.2004.00140.x

Guthrie, J. (2001). The Management, measurement and reporting of intellectual capital. Journal of Intellectual Capital, 2(1), 27-41. http://dx.doi.org/10.1108/14691930110380473

Guthrie, J., Petty, R., \& Ricceri, F. (2006). The voluntary reporting of intellectual capital: comparing evidence from Hong Kong and Australia. Journal of Intellectual Capital, 7(2), 254-271. http://dx.doi.org/10.1108/14691930610661890

Guthrie, J., Petty, R., Ferrier, F., \& Well, R. (1999). There is no accounting for intellectual capital in Australia: Review of annual reporting practices and the internal measurement of intangibles within Australian organisations. Paper presented at the International Symposium Measuring and Reporting Intellectual Capital: Experiences, Issues and Prospects, 9-10 June, Amsterdam.

Guthrie, J., Petty, R., Yongvanich, K., \& Ricceri, F. (2004).Using content analysis as a research method to enquire into intellectual capital reporting. Journal of Intellectual Capital, 5(2), 282-293. http://dx.doi.org/10.1108/14691930410533704

Haniffa, R. M., \& Cooke, T. E. (2002). Culture, corporate governance and disclosure in Malaysian corporations. Abacus, 38(3), 317-349. http://dx.doi.org/10.1111/1467-6281.00112

Healy, P. M., \& Palepu, K. G. (2001). Information asymmetry, corporate disclosure and the capital market: A review of the empirical disclosure literature. Journal of Accounting and Economics, 31, 405-440. http://dx.doi.org/10.1016/s0165-4101(01)00018-0

Hossain, M., \& Taylor, P. (2007). The empirical evidence of the voluntary information disclosure in the annual reports of banking companies: the case of Bangladesh. Corporate Ownership and Control, 4(3), 111-125. Retrieved from http://www.virtusinterpress.org/-Corporate-Ownership-and-Control-html

Hossain, M., Tan, L. M., \& Adams, M. (1994). Voluntary disclosure in an emerging capital market: Some empirical evidence from companies listed on the Kuala Lumpur Stock Exchange. The International Journal of Accounting, 29(4), 3. In S. Leventis, \& P. Weetman (Eds.), Advances in International Accounting (Vol. 17, pp. 227-250).Voluntary disclosures in an emerging capital market: Some evidence from the Athens stock exchange. http://dx.doi.org/10.1016/S0897-3660(04)17011-6

Inchausti, B. G. (1997). The influence of company characteristics and accounting regulation on information disclosed by Spanish firms. European Accounting Review, 6(1), 45-68. http://dx.doi.org/10.1080/096381 897336863

Jones, D. A. (2007). Voluntary disclosure in R\&D intensive industries. Contemporary Accounting Research, 24(2), 489-522. http://dx.doi.org/10.1506/g3m3-2532-514h-1517

Lang, M., \& Lundholm, R. (1993).Cross-sectional determinants of analyst ratings of corporate disclosures. Journal of Accounting Research, 31, 246-271. http://dx.doi.org/10.2307/2491273

Leftwich, R., Watts, R. L., \& Zimmerman, J. L. (1981). Voluntary corporate disclosure: The case of interim reporting. Journal of Accounting Research, 19, 50-77. http://dx.doi.org/10.2307/2490984

Lev, B. (2001). Intangibles: Management, measurement and reporting. Washington, DC: The Brookings Institution Press.

Lufti, R. (1989). Unlisted securities market and the disclosure of financial Information (Unpublished doctoral dissertation). University of Glasgow, Glasgow, UK.

Malone, D., Fries, C., \& Jones, T. (1993). An empirical investigation of the extent of corporate financial 
disclosure in the oil and gas industry. Journal of Accounting Auditing and Finance, 8(3), 249-273. http://dx.doi.org/10.1177/0148558X9300800306

Marr, B., Gupta, O., Pike, S., \& Roos, G. (2003). Intellectual capital and knowledge management effectiveness. Management Decision, 41(8), 771-781. http://dx.doi.org/10.1108/00251740310496288

Milne, M. J., \& Adler, R. W. (1999). Exploring the reliability of social and environmental disclosures content analysis. Accounting, Auditing and Accountability Journal, 12(2), 237-256. http://dx.doi.org/10.1108/0951 3579910270138

Mueller, F. (1996). Human resources as strategic assets: an evolutionary resource-based theory. Journal of Management Studies, 33(6), 757-786. http://dx.doi.org/10.1111/j.1467-6486.1996.tb00171.x

Nixon, B. (1997). The accounting treatment of research and development expenditure: views of UK company accountants. European Accounting Review, 6(2), 265-277. http://dx.doi.org/10.1080/713764720

Nonaka, I. (1991). The knowledge creating company. Harvard Business Review, 69(6), 96-104. http://dx.doi.org/10.1016/b978-0-7506-7009-8.50016-1

Ooghe, H., \& De Langhe, T. (2002). The Anglo-American versus the Continental European corporate governance model: empirical evidence of board composition in Belgium. European Business Review, 14(6), 437-449. http://dx.doi.org/10.1108/09555340210448794

Patton, A., \& Baker, J. C. (1987). Why won't directors rock the boat? Harvard Business Review, 65(6), 10-18. http://dx.doi.org/10.1225/87609

Penrose, E. T. (1959). The theory of growth of the firm. Wiley, New York. http://dx.doi.org/10.1093/0198289774. 003.0002

Peteraf, M. A. (1993). The cornerstone of competitive advantage: a resource-based view. Strategic Management Journal, 14(3), 179-191. http://dx.doi.org/10.1002/smj.4250140303

Raffournier, B. (1995). The determinants of voluntary financial disclosure by Swiss listed companies. The European Accounting Review, 4(2), 261-278. http://dx.doi.org/10.1080/09638189500000016

Rumelt, R. (1984). Toward a strategic theory of the firm. In R. Lamb (Ed.), Competitive Strategic Management (pp. 556-570). Prentice-Hall, Englewood Cliffs, NJ.

Seaton, J., \& Walker, I. (1997). Signalling, disclosure and the implications of financial structure for UK corporations. Economics of Innovation and New Technology, 5(1), 75-90. http://dx.doi.org/10.1080/1043859 9700000008

Singhvi, S., \& Desai, H. (1971). An empirical analysis of the quality of corporate financial disclosure. Accounting Review, 46(1), 129-138.

Spence, M. (1973). Job market signalling. Quarterly Journal of Economics, 87, 29-30. http://www.jstor.org/ stable/1882010

Spender, J.-C. (1989). Industry recipes: The nature and sources of managerial judgement. Blackwell, Oxford. http://dx.doi.org/10.1177/017084069101200221

Sveiby, K. E. (1997). The new organisational wealth: managing \& measuring knowledge based assets. Berrett-Koehler, San Francisco, CA.

Teece, D. (1980). Economies of scope and the scope of the enterprise. Journal of Economic Behaviour \& Organization, 1(3), 223-247. http://dx.doi.org/10.1016/0167-2681(80)90002-5

Teece, D., Pisano, G., \& Sheun, A. (1997). Dynamic capabilities and strategic management. Strategic Management Journal, 18(7), 509-33. http://dx.doi.org/10.1016/b978-0-7506-7088-3.50009-7

Toms, S. (2002). Firm resources, quality signals and the determination of corporate environmental reputation: some UK evidence. The British Accounting Review, 34(3), 257-282. http://dx.doi.org/10.1006/bare.2002. 0211

Verrecchia, R. E. (1983). Discretionary disclosure. Journal of Accounting and Economics, 5, 174-194. http://dx.doi.org/10.1016/0165-4101(83)90011-3

White, H. (1980). A heteroskedasticity-consistent covariance matrix and a direct test for heteroskedasticity. Econometrica, 48(4), 817-838. http://dx.doi.org/10.2307/1912934

Wright, P. M., McMahan, G. C., \& McWilliams, A. (1994). Human resources and sustained competitive 
advantage: a resource-based perspective. International Journal of Human Resource Management, 5(2), 301-326. http://dx.doi.org/10.1080/09585199400000020

Zarzeski, M. T. (1996). Spontaneous harmonisation effects of culture and market forces on accounting disclosure practices. Accounting Horizons, 10(1), 18-37. Retrieved from http://ssrn.com/abstract=2600

\section{Note}

Note 1. Investment in strategic human resource assets (Mueller, 1996; Wright et al., 1994) is a sufficient but not a necessary condition for realized super-normal profits, since the employment of such assets simultaneously leads to the creation of internal rent appropriation possibilities.

\section{Copyrights}

Copyright for this article is retained by the author(s), with first publication rights granted to the journal.

This is an open-access article distributed under the terms and conditions of the Creative Commons Attribution license (http://creativecommons.org/licenses/by/3.0/). 